Originalveröffentlichung in: Rommevaux, Sabine ; Vendrix, Philippe ; Zara, Vasco (Hrsgg.): Proportions. Science, musique, peinture \& architecture ; actes du Lle Colloque International d'Études Humanistes 30 juin - 4 juillet 2008. Turmhout 2011, S. 443-456 (Études renaissantes ; 6)

\title{
Anthropomorphism. Towards a Social History of Proportion in Architecture
}

\author{
Frank Zöllner \\ Universität Leipzig
}

\begin{abstract}
Anthropomorphism is one of the most popular notions in cultural history. Even in inorganic areas such as architecture it still plays a prominent role. In particular, when theoretical reflections about buildings and their parts were made, architects, architectural theorists and laymen readily made use of the metaphor of the human body, which was regarded as a direct symbolic image of the building and its parts. This process included the definition and metaphorical description of both body and building utilizing measurements, proportions and geometrical figures ${ }^{1}$. All elements of the anthropomorphist metaphor can already be found in the writings of Vitruvius' De architectura libri decem $^{2}$. Vitruvius describes anthropomorphism quoting as an example the activities of the greek
\end{abstract}

I Further reading, especially on anthropomorphism, includes : Maria Brzóska, Anthropomorphe Auffassung des Gebäudes und seiner Teile, Jena, Diederichs, 1931; Suzanne Preston Blier, «Houses Are Human : Architectural Selfimages of Africa's Tamberma ", Journal of the Society of Architectural Historians, XIII, 1983, p. 371-382; Paul von Naredi-Rainer, Architektur und Harmonie. Zahh, Maß und Proportion in der abendländischen Baukunst, Cologne, DuMont, 1982; Frank Zöllner, Vitruvs Proportionsfigur. Quellenkritische Studien zur Kunstliteratur des 15. und 16. Jahrhunderts, Worms, Werner, 1987; John Onians, Bearers of Meaning. The Classical Orders in Antiquity, the Middle Ages and the Renaissance, Princeton, Princeton University Press, 1988, p. 162-165 and passim; Bruno Reudenbach, "Die Gemeinschaft als Körper und Gebäude: Francesco di Giorgios Stadttheorie und die Visualisierung von Sozialmetaphern im Mittelalter ", in Klaus Schreiner \& Norbert Schnitzler (eds), Gepeinigt, begehrt und vergessen. Symbolik und Sozialbezug des Körpers im späten Mittelalter und in der frühen Neuzeit, Munich, Fink, 1992, p. 171198; Ralf Weber \& Sharon Larner, "The Concept of Proportion in Architecture : An Introductory Bibliographic Essay ", Art Documentation, IV/12, 1993, p. 147-154; Marcus Frings, Mensch und Maß: Anthropomorphe Elemente in der Architekturtheorie des Quattrocento, Weimar, VDG, 1998; Ivan Muchka, "Anthropomorphismus in der Architektur um 1600 ", in Lubomír Konecny et alii (eds), Rudolf II, Prague and the World, Prague, Artefactum, 1999, p. 57-63; Jay M. Bernstein, "Aporia of the Sensible. Art, Objecthood and Anthropomorphism ", in Ian Heywood \& Barry Sandywell (eds), Interpreting Visual Culture. Explorations in the Hermeneutics of the Visual, London, Routledge, 1999, p. 218-237; George Dodd \& Robert Tavernor (eds), Body and Building. Essays on the Changing Relation of Body and Architecture, Cambridge, Cambridge University Press, 2002; Otto Neumaier (ed.), Ist der Mensch das Maß aller Dinge? Beiträge zur Aktualität des Protagoras, Möhnesee, Bibliopolis, 2004.

2 Further reading on Vitruvius and his historical reception : Lucia A. Ciapponi, Vitruvius, in Edward F. Cranz (ed.), Catalogus translationum et commentariorum, Washington D.C., Catholic University of America 
architect Dinocrates ${ }^{3}$ and elucidating the Doric column ${ }^{4}$. However, the most extensive comments regarding the human measure as a measure of and as a metaphor for architecture are found at the beginning of the third book. Here he states that the shape of sacred architecture is based on symmetry and proportion and that this design corresponds with the accurate composition of the human bodys. He even derives the specific units of measurement from the human body, and states that from a man with out-stretched arms and legs two geometrical figures, square and circle, are derived, the so called " homo ad quadratum " and the " homo ad circulum ". In this concept, the navel is assumed to be the center of the body ${ }^{6}$.

Since Rudolf Wittkower's book Architectural Principles in the Age of Humanism, published in 1949, the " homo ad circulum " described by Vitruvius together with his alter ego, " homo ad quadratum ", are regarded as symbols of Renaissance architecture ${ }^{7}$. However, upon closer investigation it turns out that Rudolf Wittkower subsequently added this figure to his interpretation of the Renaissance architecture as a device, which stood closer to a rather forced symbolic understanding of architecture of the 2oth century than to architectural views of the Renaissance. As a matter of fact, the figure described by Vitruvius had no direct influence on the architecture of the isth and

Press, 1976, III, p. 399-40I; Georg Germann, Einführung in die Geschichte der Architekturtheorie, Darmstadt, Wissenschaftliche Buchgesellschaft, 1980; Louis Callebat, Pierre Bouet et alii (eds), Vitruve, De Architectura : Concordance, Hildesheim, Olms-Weidmann, 1984; Pier Nicola Pagliara, Vitruvio da testo a canone, in Salvatore Settis (ed.), Memoria dell'antico nell'arte italiana, 3 vols., Turin, Einaudi, 1984-1986, III, p. 3-85; Günther Fischer, Vitruv NEU oder Was ist Architektur, Basel, Birkhäuser, 2009.

3 Vitruvius, De architectura libri decem, edited and annotated by Curt Fensterbusch, Darmstadt, Wissenschaftliche Buchgesellschaft, 1981, book 2, Proemium.

$4 \quad$ Ibid., 4.I.6. Cf. J. Onians, Bearers of Meaning..., op. cit.

5 Vitruvius, De architectura..., op. cit., III, I : "Aedium compositio constat ex symmetria, cuius rationem diligentissime architecti tenere debent. Ea autem paritur a proportione, quae graece analogia dicitur. Proportio est ratae partis membrorum in omni opere totoque commodulatio, ex qua ratio efficitur symmetriarum. Namque non potest aedi ulla sine symmetria atque proportione rationem habere compositionis, nisi uti [ad] hominis bene figurati membrorum habuerit exactam rationem ". See also F. Zöllner, Vitruvs Proportionsfigur..., op. cit.; Vitruve, De l'architecture, texte établi, traduit et commenté par Pierre Gros, Paris, Les Belles Lettres, 1999, III, p. 55-78; Giacomo Berra, "La storia dei canoni proporzionali del corpo umano e gli svilluppi in area lombarda alla fine del Quattrocento ", Raccolta Vinciana, XXV, 1993, p. 159-310; Burkhardt Wesenberg, "Vitruv und Leonardo in Salamis. Vitruvs Proportionsfigur und die metrologischen Reliefs ", Jahrbuch des Deutschen Archäologischen Instituts, I16, 2001 (2002), p. 357-380; Indra Kagis McEwan, Vitruvius. Writing the Body of Architecture, Cambridge, Cambridge University Press, 2003.

6 Vitruvius, De architectura..., op. cit., III, I-3 : " Item corporis centrum medium naturaliter est umbilicus. Namque si homo conlocatus fuerit supinus manibus et pedibus pansis circinique conlocatum centrum in umbilico eius, circumagendo rotundationem utrarumque manuum et pedum digiti linea tangentur. Non minus quemadmodum schema rotundationis in corpore efficitur, item quadrata designatio in eo invenietur. Nam si a pedibus imis ad summum caput mensum erit eaque mensura relata fuerit ad manus pansas, invenietur eadem latitudo uti altitudo, quemadmodum areae, quae ad normam sunt quadratae ”.

7 Rudolf Wittkower, Architectural principles in the Age of Humanism, London, Warburg Institute, University of London, 1949. 
16th centuries. ${ }^{8}$ The concept of the building constructed according to the anthropomorphist ideas was not directly applicable to architecture because no building actually received the shape of a human body. Only the abstract idea underlying an architect's design could correspond with an anthropomorphist view. In the following, I will give examples from architectural theory in order to discuss the importance this metaphorical reference had for architects and theorists. In doing so, I would like to illustrate how and why, within the theory of architecture in the isth until the 19th century, the anthropomorphist notion of architecture slowly lost importance and why it was finally explicitly questioned. In the end, I will deal with the revival of anthropomorphism in Architectural Romanticism of the 20 th century.

\section{Vitruvius, the Human Measure and Ancient Metrology}

Vitruvius' specification of the measurements of the human body are based on the practice drawn from the ancient construction site and on Greek metrology, the science of measurement ${ }^{10}$. The measurements, which Vitruvius defines in this context, are approximate values derived from the actual dimensions of various parts of the body. In Vitruvius' first and third book, a number of these anthropomorphist measurements are mentioned : digit, palm, span and cubit, which were referred to as " digitus ", " palmus ", " pes " and " cubitus " in the original text (see Appendix I). The same measurements were the basis of the anthropomorphic system of measurement, which was applicable to all areas of human life ${ }^{\mathrm{It}}$. These anthropomorphic measurements were only substituted by a geomorphological system, based on the measurements of the earth, when the metric system was being introduced. The French National Assembly first introduced the metric system in 1795 and promoted the introduction of the meter according to the Meter Convention, agreed upon in 1875 .

F. Zöllner, Vitruvs Proportionsfigur..., op. cit. For reception of this perspective see the following reviews : John Onians, Newsletter of the Society of Architectural Historians of Great Britain, Winter, 1988; Günter Binding, Archiv fur Begriffsgeschichte, LXXI, 1989, p. 5II-513; Carolyn Kolb, Journal of the Society of Architectural Historians, LII, 1993, p. 359-360 as well as the response by Frank Zöllner, Journal of the Society of Architectural Historians, LIII, 1994, p. 377 and Id., "L'uomo vitruviano di Leonardo da Vinci, Rudolf Wittkower e l'Angelus Novus di Walter Benjamin ", Raccolta Vinciana, XXVI, 1995, p. 329-358.

9 S. Preston Blier, "Houses Are Human... ", art. cit.; Jan Pieper, " Houses of Narzissus. Architecture According to the Image of Man ", Daidalos, XLV, 1992, p. 31-47.

Io Vitruvius, De architectura..., op. cit., I, 2, 4; III, I, I-9; II, 3, 3; III, I, 7; VI, 8, 9. About antique metrology cf. Friedrich Hultsch, Griechische und römische Metrologie, $2^{\text {nd }}$ edition, Berlin, Weidmannsche Buchhandlung, 1862, esp. p. 30-74; James A. Kane, The Ancient Building Science, Ann Arbor, Edward Brothers, 1940; Eivind Lorenzen, Technological Studies in Ancient Metrology, Copenhagen, Nyt Nordisk Forlag, 1966; Thomas Thieme, « Metrology and Planning in the Basilica of Johannes Stoudios ", in Jean-François Bommelaer (éd.), Le dessin d'architecture dans les societés antiques, Actes du colloque de Strasbourg 26-27 janvier 1984, Strasbourg, Université de Sciences Humaines de Strasbourg, 1985, p. 291-308; Eric Fernie, " Historical Metrology and Architectural History ", Art History, I, 1978, p. 383-399; F. Zöllner, Vitruvs Proportionsfigur..., op. cit., p. 23-43; Vitruve, De l'architecture..., op. cit., III, p. 55-78.

Vitruvius, De architectura..., op. cit., I, 2, 4 and III, I, 5-8. 


\section{Anthropomorphism in the 15th and early I6th century}

In the Middle Ages the metaphorical comparison between the human body and buildings was developed independently from Vitruvius' ideas ${ }^{12}$. The comparison did not serve as a scheme for the design, but simply as a basis for interpreting buildings a posterior $t^{23}$. This tradition of posterior interpretation was used by architectural and art theorists of the Quattrocento, who had received practical training, for example Francesco di Giorgio Martini (I439-I5OI), an architect, engineer and painter from Siena. He primarily used the anthropomorphistic comparison between buildings and the human body in the early version of his treatise on architecture, which was not yet fully matured (fig. I).

FIG. 1

Francesco di Giorgio Martini, Anthropomorphic illustration, 1480, Florenz, Biblioteca Laurenziana, Codex Ashb. 36r.

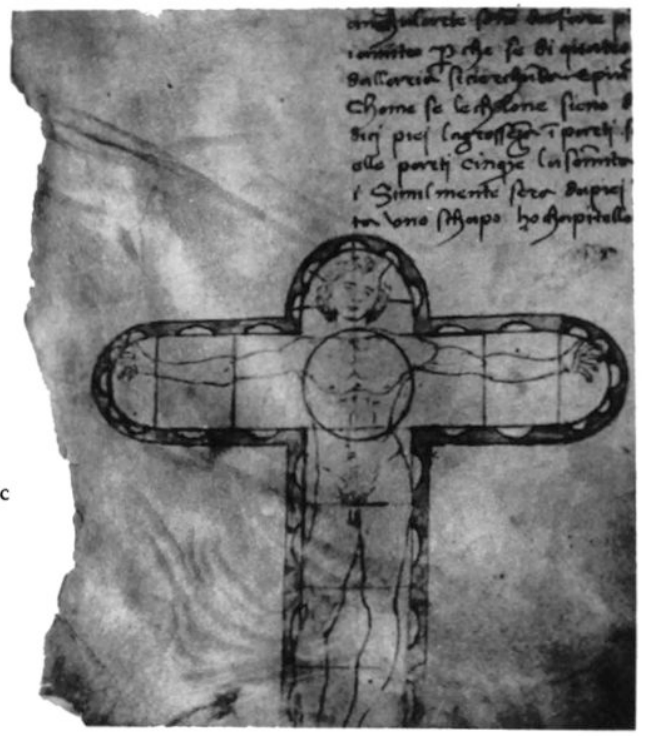

12 Cf. medieval sources cited by Victor Mortet, Recueil de textes relatifs à l'histoire de l'architecture et à la condition des architectes en France en Moyen Âge, 2 vols., Paris, CTHS, I9II-1929, I, p. 157-16I, II, p. 183-188; Hans Liebeschütz, Das allegorische Weltbild der Heiligen Hildegard von Bingen, "Studien der Bibliothek Warburg " 16, Leipzig-Berlin, 1930, p. 3I-34; Günter Bandmann, Mittelalterliche Architektur als Bedeutungsträger, Berlin, Gebrüder Mann, 195I, p. 65; Bruno Reudenbach, "In mensuram humani corporis". Zur Herkunft der Auslegung und Illustration von Vitruv III I im 15. und 16. Jahrhundert ", in Christel Meuer \& Uwe Ruberg (hrg.), Text und Bild. Aspekte des Zusammenwirkens zweier Künste in Mittelalter und früher Neuzeit, Wiesbaden, Reichert, 1980, p. 651-688, spec. $675-676$.

13 Cf. V. Mortet, Recueil..., op. cit., I, p. I59-160, n. 3. The reasoning of this source, as well as of the following sources, largely follows F. Zöllner, Vitruvs Proportionsfigur..., op. cit., p. 44-76. 
Around 1480 , Francesco di Giorgio tied the sketch and the floor plan of a building directly to the figure of the person and therefore created a connection between the medieval concept of anthropomorphism and Vitruvius' proportional figure ${ }^{14}$. From the point of view of an anthropomorphistic understanding of architecture, Vitruvius' proportional figure did not represent any important innovation to the engineer and architect from Siena. However, it granted him the opportunity to give the anthropomorphism of the Middle Ages an ancient air. A similar approach can be found in the treatises of Lorenzo Ghibertits and Antonio Averlino detto il Filarete ${ }^{16}$.

Considering Quattrocento theories of art and architecture one can therefore conclude, that anthropomorphism appeared in early stages of the development of architectural theory and it is predominantly quoted by theorists, hoping to achieve social recognition in their field. Francesco di Giorgio's treatises are a good example of the decreasing importance of anthropomorphism starting towards the end of the Quattrocento : in the second version of his treatise, anthropomorphism had less importance in comparison to the first version of the text, which was still on a lower level of theoretical sophistication.

The explanations on Vitruvius' proportional figure by Cesare Cesariano, a Milanese surveyor and architect, in his commentary on Vitruvius, published in 1521, are also to be considered in the context of a lower social status and a lesser level of theory formation ${ }^{17}$. Descending from a very modest social background, Cesariano was treated poorly by his stepmother. Though as a land surveyor and architect he had gained some reputation in Milan and other places in northern Italy. Just like his role model Vitruvius, he made an effort to strengthen his artistic self-image and improve his social standing by means of literary and theoretical writings. Cesariano's intentions are illustrated by a full-page woodcut with allegorical images depicting his life, the so-called autobiographical page, which appeared in his commentary on Vitruvius. At the center of the illustration, the author is shown leading to spheres of enhanced felicity and elevated social status by the goddess of audaciousness, audacia. He holds the instruments of an architect in his hand : dividers and straightedge, the significance of which for taking the measurements of the construction site, models and buildings

Francesco di Giorgio Martini, Trattato di architettura ingegneria e arte militare, a cura di Corrado Maltese, 2 vols., Milano, il Polifilo, 1967, I, p. 20. Cf. also Richard Johnson Betts, The Architectural Theories of Francesco di Giorgio Martini, Princeton, Princeton University Press, 1971, p. 55-59 and p. 89; Lawrence Lowic, "The Meaning and Significance of the Human Analogy in Francesco di Giorgio's Trattato ", Journal of the Society of Architectural Historians, XLII, 1983, p. 360-370; F. Zöllner, Vitruvs Proportionsfigur..., op. cit., p. 72-76; B. Reudenbach, Gemeinschaft als Körper..., op. cit., esp. p. 171-176; Francesco Paolo Fiore \& Manfredo Tafuri, Francesco di Giorgio architetto, Milano, Electa, 1993, p. 363-365. Lorenzo Ghiberti, Denkwürdigkeiten (I Commentarii), hrsg. und erläutert von Julius von Schlosser, 2 vols., Berlin, Bard, 1912, I, p. 227-231, esp. p. 228; Klaus Bergdolt, Der dritte Kommentar Lorenzo Ghibertis, Weinheim, VCH, Acta Humaniora, 1988, p. 550-554, 562-568, and p. xxxi-xxxii, lxi, lxvii, lxxvi-lxxvii, xci-xciv. Antonio Averlino detto il Filarete, Trattato di architettura, a cura di Anna Maria Finoli \& Liliana Grassi, 2 vols, Milano, Il Polifilo, 1972, I, p. 18-2I (f. 3v-4r and 6r). 
are also explained by the autor ${ }^{18}$. The book under his left arm is a reference to his commentary on Vitruvius. In the corresponding text Cesariano writes : Equipped with dividers and straightedge as well as with the commentary on Vitruvius, he joined audacia in order to escape from poverty and from his stepmother's despotic rule ${ }^{19}$. Cesariano chose precisely the instruments which guarantee the correct measure in architecture, hoping to raise his social status.

In connection with his examination of Vitruvius' proportional figure, Cesariano explains the importance of the precise anthropomorphic measurements for architectural designs and the dimensions of the building under construction as well as the relevance of the necessary instruments : the man in the square exemplifies the concept of "symmetriata quadratura ", i.e. he illustrates the possibility of determining the size of all surfaces using geometry and the anthropomorphist measurements (fig. 2).

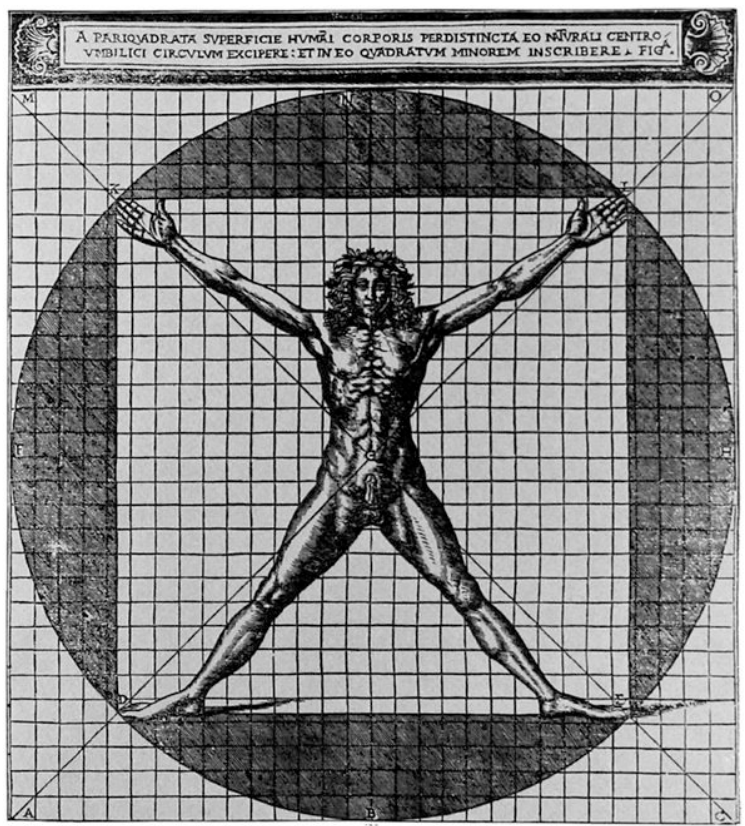

FIG. 2

Cesare Cesariano, Vitruvian man (homo ad quadratum) from his $D i$ Lucio Vitruvio Pollione de Architectura Libri Dece traducti de latino in Vulgare [...], Como, I52I (Reprint, Munich, 1969), f. sov.

18 Ibid., f. I3ir.

19 Ibid., f. 9IV-92r; cf. also Carol Herselle Krinsky, Cesare Cesariano and the Como Vitruvius Edition of I521, Ann Arbor, Michigan University Press, 1965, p. 297-300; and Paolo Verzone, "Cesare Cesariano ", Arte Lombarda, XVI, 1971, p. 203-210. 
Cesariano also mentions various measuring instruments of different dimensions, including the bacculo ligneo, which has the length of an ulna. He also specifies long measuring instruments, for instance the trabucco, which has a length of six feet, as well as the longest calibrated straightedge, the ten feet pertica and the fathom (Greek orguia), which is illustrated by Vitruvius in his " homo ad quadratum $"^{20}$. Based on these instruments, Cesariano emphasizes that the units of measurements needed to measure both land and buildings are derived directly from the human body.

The text written by Cesariano reveals a competent understanding of anthropomorphic measurements and of Vitruvius' view of architecture. Cesariano's precise understanding is owed to the fact that he underwent a practical training as an architect and land surveyor. Skilled in his trade, he had detailed knowledge in the practice of measuring, which, in regards to the instruments used and the deduction of the anthropomorphist measurements, was nearly identical to the practice that Vitruvius had based his thoughts on. Despite the fact that his illustrations of the Vitruvian Man are not among the most impressive of their kind, the corresponding text clearly documents the importance the theorist Cesariano gave to the deduction of architectonic measurements based on the human body. Similar to the theorists of the Quattrocento, precise knowledge of the practical side of his craft lead to an affinity towards the theoretical concept of anthropomorphism.

\section{Musical Harmonies versus Anthropomorphism}

During the early Renaissance, the majority of architectural theorists came from a social class, which only received a fairly simple craftsmen's like education. This is one of the reasons why they linked their theories, some of which seemed rather naïve, to an anthropomorphism, which was prevalent in the Middle Ages. It lent the prestige of an ancient theory by incorporating Vitruvius' proportional figure. However, a more sober attitude towards anthropomorphism was adopted by the following generations of architects and theorists. In comparison to the metaphoric derivation, which directly deduced architectonic measurements from the human body, these theorists put more emphasize on musical proportions. As a result, the leading architectural theorists of the Renaissance based their theoretical considerations on music, for instance Leon Battista Alberti in the 15 th century ${ }^{21}$ and Andrea Palladio in the 16 th century ${ }^{22}$. To these theorists, who emanated

20 C. Cesariano, Di Lucio Vitruvio..., op. cit., f. $48 \mathrm{v}$ and $143 \mathrm{r}$.

2I Leon Battista Alberti, De re aedificatoria, Firenze, N. Alamani, I485, used in his 1912 edition, by Max Theuer, Leipzig, Hugo Heller \& Co., IX, 5-6 (musical harmony) and VII, s (anthropomorphism). Cf. also Peter Hugh Schofield, The Theory of Proportion in Architecture, Cambridge, Cambridge University Press, 1958, p. 57; Leon Battista Alberti, a cura di Joseph Rykwert \& Anne Engel, Milan, Electa, 1994, especially Paul von Naredi-Rainer, "La bellezza numerabile : l'estetica architettonica di Leon Battista Alberti ", p. 292-299, and Robert Tavernor, "Concinnitas, o la formulazione della bellezza ", p. 300-315.

22 Andrea Palladio, I Quattro libri dell'architettura, Venice, Domenico de' Franceschi, 1570 (reprint : Milano, Hoepli, 1980), I, p. 6 (I.I, Anthropomorphism) and vol. II (musically determined proportional systems). Further expansion of Palladios' proportional systems : R. Wittkower, Architectural Principles..., op. cit., p. Io-I24; Deborah Howard 
from a higher social class (e.g. Leon Battista Alberti) or had obtained a higher level of theoretical reflection through the benefits of intellectual facilitation (e.g. Palladio), the metaphor of the human measurement must have seemed much less appealing than to men of lower social rank or lower education. By this new type of theorists the metaphoric comparison with the human measures was increasingly replaced by attempts to determine precise musical harmonies like fourths, fifths and octaves, in order to describe analogies, or assumed analogies, between entire buildings and their parts. The church of San Francesco della Vigna in Venice is the most prominent example of this approach ${ }^{23}$.

Taking a closer look at the writings of Daniele Barbaro, author of the most relevant commentary on Vitruvius throughout the 16th century, it becomes clear that the theoretical formation of anthropomorphism was increasingly raised to a more abstract level. In 1556, Barbaro published the first edition of his writings on Vitruvius in Latin and, when the second edition was released in Italian in 1567 , the proportional figure was mentioned but did not receive an illustration. Furthermore, it was Barbaro who entirely replaced Vitruvius' anthropomorphist measurements with the proportional system, which was based on musical harmonies ${ }^{24}$ and did not have any connection with ancient measuring systems. Not much later, the Vincentian master builder Andrea Palladio adopted Barbaro's proportional system to a larger extent than anyone before, both in his theoretical reflection and in the practical application. Consequently, in Palladio's treatise on architecture, anthropomorphism no longer was of any relevance. This decline in significance was mainly due to the fact that intellectually well-versed authors, such as Alberti and Barbaro, the ideas of whom had paved the way for Palladio, all replaced the anthropomorphist view of architecture with a rational proportional system based on music theory. This system had the advantages of being directly applicable to building practice ${ }^{25}$ and it was credibly associated with cosmic harmonies, which were believed to be musical ${ }^{26}$.

\& Malcom Longair, " Harmonic Proportion and Palladio's Quattro Libri ", Journal of the Society of Architectural Historians, XLI, 1982, p. I16-I43; Branko Mitrovic, "Palladio's Theory of Proportions and the Second Book of the Quattro Libri dell'Architettura ", Journal of the Society of Architectural Historians, XLIX, 1990, p. 279-292.

Cf. R. Wittkower, Architectural Principles..., op. cit., p. 90-94; Antonio Foscari \& Manfredo Tafuri, L'armonia e i conflitti. La chiesa di San Francesco della Vigna nella Venezia dell'soo, Torino, Einaudi, 1983, p. 208-209.

Daniele Barbaro, I dieci libri dell'architettura di M. Vitruvius. Tradotti \& commentati [...], Venezia, Francesco Marcolini, 1567, edited by Manfredo Tafuri \& Manuela Morresi, Milano, Il Polifilo, 1987, p. 96-108. Cf. Diego Horacio Feinstein, Der Harmoniebegriff in der Kunstliteratur und Musiktheorie der italienischen Renaissance, Ph.D. dissertation, Freiburg i. Br., Wasmuth, 1977, p. 135-143; F. Zöllner, Vitruvs Proportionsfigur..., op. cit., p. 155-169; for the two editions see Louis Cellauro, "Les éditions de Vitruve par Daniele Barbaro à Venise chez Marcolini en 1556 et chez de' Franceschi en 1567 ", in Sylvie Deswarte-Rosa (éd.), Sebastiano Serlio à Lyon : architecture et imprimerie, I. Le traité d'architecture de Sebastiano Serlio : Une grande entreprise éditoriale au XVt siècle, Lyon, Mémoire Active, 2004, p. 392-396.

25 D. Howard \& M. Longair, "Harmonic Proportions... ", art. cit.

26 R. Wittkower, Architectural Principles..., op. cit., p. IIO-I24. 


\section{The End of Anthropomorphism}

The idea of anthropomorphism in architecture was even more radically put into question by the French theory of architecture during the 17 th century. This doubting is demonstrated most clearly by Claude Perrault's translation of Vitruvius, first published in 1674, with the second edition appearing in $1684^{27}$. In the translation's footnotes, Perrault outlines his perspective on proportions, which was contrary to the traditional perception. He categorically opposed to the idea of traditionally assumed rules of proportion, which are applicable to architecture like laws of nature. Vitruvius derived the origin of Doric columns from the length of the human foot ${ }^{28}$, while Perrault's commentary explicitly objects to Vitruvius' perception, which had predominated thus far. Perrault argues that proportions in architecture are by no means natural and do not

follow any unalterable rules, such as the dimensions of the stars or the dimensions of parts of the human body. According to Perrault, architects base the proportions of buildings on conventions and consensus which are defined by tradition as well as by custom $^{29}$. Consequently, it is not human measurements but rather human habitualness that underlies the beauty of art.

Of course there were objection $s^{30}$ towards Perrault's departure from the anthropomorphist theory of proportions; nevertheless, theories of the 18th to the 2oth century were influenced by this point of view ${ }^{31}$. This could be the reason why Berardo Galiani did not pay much attention to the human measurements in his commentary on Vitruvius, published in 1758 . The reconstruction of dimensions, which are relevant as measurements, had lost predominance in his illustration of Vitruvius proportional figure (fig. 3).

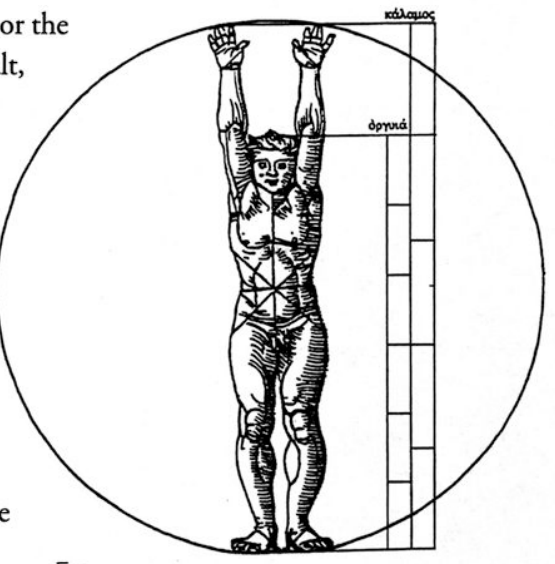

FIG. 3

Vitruvius' canon of proportions and homo ad circulum defined as measuring rod (reconstruction F. Z.).

Claude Perrault, Les dix livres d'architecture de Vitruve corrigez et traduits nouvellement en Francois, Paris, Jean-Baptiste Coignard, 1684 (reprint : Paris, Balland, 1979). Cf. Wolfgang Herrmann, The Theory of Claude Perrault, London, Zwemmer, 1973; Antoine Picon, Claude Perrault, ou la curiosité d'un classique, Paris, Picard, 1988, p. II5-135; Henry Millon, "The French Academy of Architecture. Foundation and Program ", in June Hargrove (ed.), French Academy, Classicism, and its Antagonists, Newmark, University of Delaware Press, 1990, p. 68-77. See supra, n. 4.

29 Cl. Perrault, Les dix livres d'architecture..., op. cit., p. II, I04-105. On Perrault and his theory see also P. H. Schofield, Theory of Proportion..., op. cit., p. 27-73; Walter Kambartel, Symmetrie und Schönheit. Über mögliche Voraussetzungen neueren Kunstbewußtseins in der Architekturtheorie Claude Perraults, Munich, Fink, 1972; Alberto Pérez-Gómez, Architecture and the Crisis of Modern Science, Cambridge (Mass.)-London, MIT Press, 1983, p. 32-39.

30 A. Pérez-Gómez, Architecture and the Crisis..., op. cit., p. 39-47; Hanno-Walter Kruft, Geschichte der Architekturtheorie, München, Beck, 2004, p. I48-150. P. H. Schofield, Theory of Proportion..., op. cit., p. 76-80. 


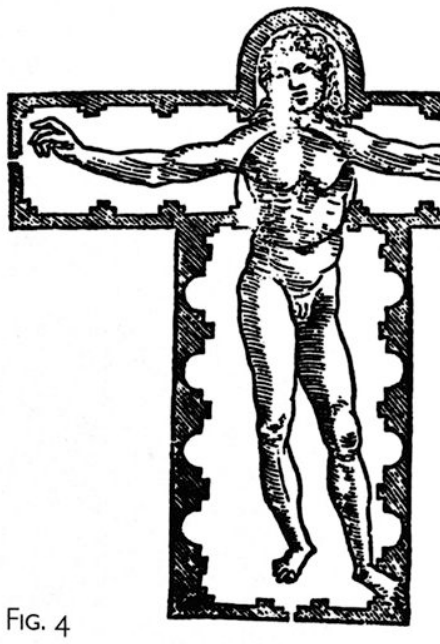

Pietro Cataneo, Proportional figure of a groundplan of a church from Pietro Cataneo, I quattro primi libri di architettura, Venice, I554, f. 35.
Galliani even explicitly opposed taking the anthropomorphist perspective too seriously. In this context, he criticized Pietro Cataneo for tying the proportional figure directly to the ground plan of a church in 1567 . In Galiani's view, Cataneo's traditional illustration (fig. 4) of his conception must have been the result of misunderstanding Vitruvius ${ }^{32}$.

The introduction of the meter in the igth century reinforced the departure from the idea that the man was the measure of all things. The meter and the decimal measuring system replaced the anthropomorphic measurements and the duodecimal system in continental Europe. Even though the human body still was occasionally compared to buildings and their parts ${ }^{33}$, anthropomorphism, as a metaphor in architecture, kept loosing importance. Consequently, in early igth century, Jean-Nicolas-Louis Durand (1760-1834) denied any connection between architecture and the human body. For instance he opposed the concept of deriving the proportions of columns from human measurements and suggested instead that they were proportioned arbitrarily ${ }^{34}$. Other theorists such as Eugène Emmanuel Viollet-Le-Duc (1814-1879) and Auguste Choisy (I84I-1909) assumed the concept of proportion to be dependent on statics and geometry ${ }^{35}$. British theorists have argued similarly ever since the 18 th century ${ }^{36}$. Despite the fact that anthropomorphic measurements and the related duodecimal calculation retained their influence in Anglo-American culture until the 2oth century, the departure from anthropomorphism was due to the empiric and rational attitude ${ }^{37}$.

Berardo Galiani, L'architettura di M. Vitruvio Pollione colla traduzione italiana e comento del Marchese Berardo Galiani, Napoli, Simoniana, 1758, p. 94 and table 4; Pietro Cataneo, I quattro primi libri di architettura, Venezia, Aldo Manuzio, I554, f. 35, and Id., L'architettura libri otto, Venezia, Aldo Manuzio, I567 (reprint : Bologna, Forni, 1982), p. 75-76.

33 See e.g. Joseph Gwilt, An Encyclopedia of Architecture, London, Longmans/Green, 1867 (reprint : New York, Random House, 1982), p. 796 and 802; H.-W. Kruft, Geschichte der Architekturtheorie..., op. cit., p. 328.

34 Jean-Nicolas-Louis Durand, Précis de lecons d'architecture données à l'École Royale Polytechnique, Paris, École Royale Polytechnique, I817-1819 (1802-1805, Reprint, Nördlingen, Uhl, 1985), p. 5, 8-14.

35 Eugène Emmanuel Viollet-le-Duc, Dictionnaire raisonné de l'architecture francaise du Xf au XVt siècle, Io vols., Paris, Morel, 1854-1868 (Reprint, Paris, Hermann, 1964), VII, p. 534; August Choisy, Histoire de l'architecture, 2 vols., Paris, Gauthier-Villars, 1899 (Reprint, Genf-Paris, Editions Vincent, Freal et Cie, 1982), II, p. 764, following H.-W. Kruft, Geschichte der Architekturtheorie..., op. cit., p. 323 and 328.

36 P. H. Schofield, Theory of Proportion..., op. cit., p. 76-80; Heinz Bienefeld, "Bedeutung und Verlust des Schönen in der Kunst : Proportion und Material als Wesensmerkmale der Architektur ", Das Münster, II/46, 1993, p. II5-II9.

37 For example in : Joseph Gwilt, Encyclopedia of Architecture, London, Longman, Brown, Green \& Longmans, 1842, the later edition in 1867 was augmented by Edward Cresys' observations on the "Principles of Proportion ", p. 766 . 


\section{The Romantic Renaissance of Anthropomorphism in the 2oth century}

The early industrialization of Britain can be perceived as one of the reasons for the departure from anthropomorphism, as it favored a concept of architecture that was primarily functional and empirical. On the other hand, the serial production of single architectonic components, introduced about one hundred years after the beginning of industrialization, was partially responsible for the ideological rebirth of the anthropomorphist theory of proportions. The best known attempt to revive anthropomorphism in architecture was made by Le Corbusier with his Modulor (fig. 5).

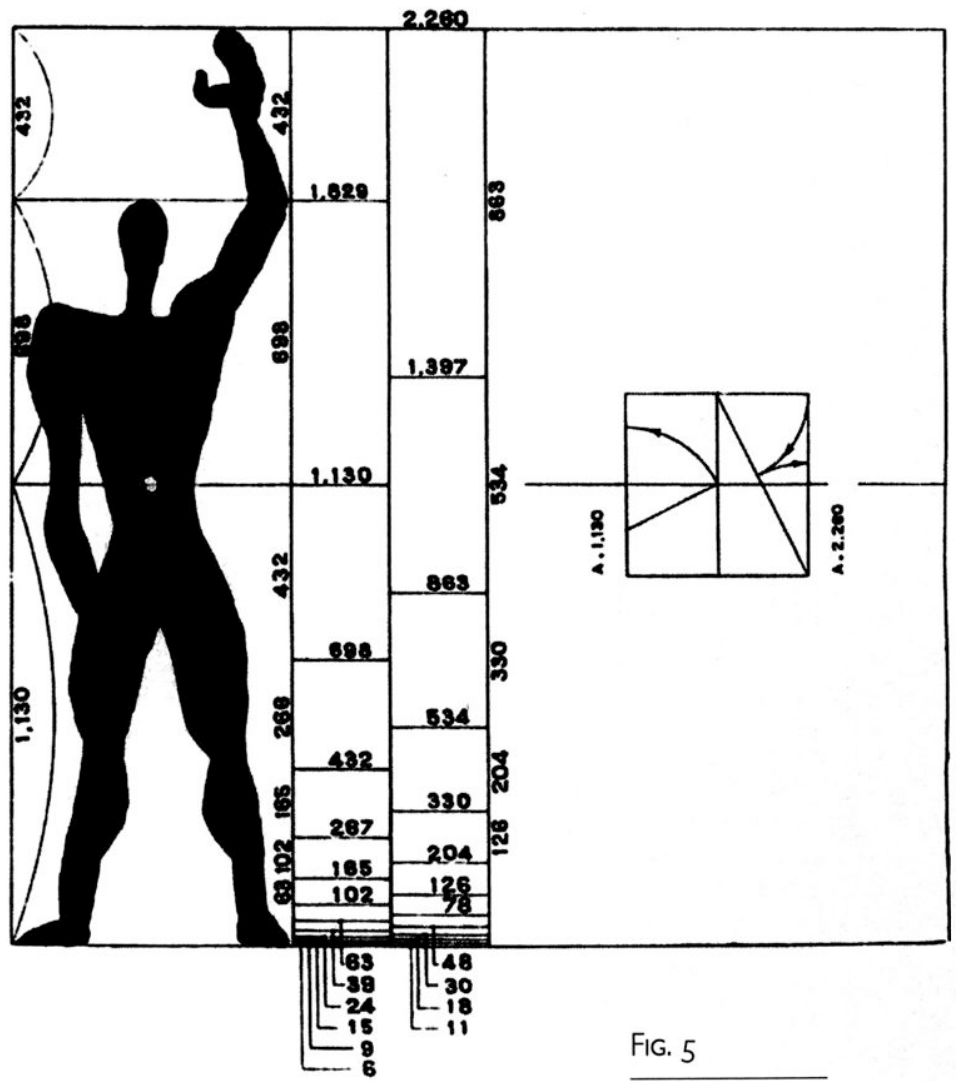

Le Corbusier, The Modulor, 1950. 
Actually, one of the main thoughts, expressed in the Modulor is the connection to serial production and standardization of architectonic components ${ }^{38}$. An architect and painter, Le Corbusier already started developing his ideas in 1943 in Paris and presented them to the public in America in 1947. In February 1948 an explanation of the Modulor was published by Matila Ghyka in the magazine The Architectural Review. Le Corbusiers' final written version of the Modulor was finished by 1948 and published in 1950 under the original title : Le Modulor - Essai sur une mesure harmonique à l'échelle humaine applicable universellement à l'architecture et à la mécaniques.

According to Le Corbusier, the Modulor originated from the feeling of mental oppression and material distress caused by the German occupation of France in World War $\mathrm{II}^{40}$. The measurement system of the Modulor considered the average human size and was additionally based on a mathematical and proportional law of nature. In order to accomplish this, he applied the Golden Section - sectio aurea - to the dimensions of the human body. Le Corbusier originally determined the height of the body at $175 \mathrm{~cm}$ ( $5.7 \mathrm{feet}$ ) but then decided to finalize it at $183 \mathrm{~cm}$ ( 6 feet). The distance from the soles of the feet to the tip of vertically outstretched arm measured $226 \mathrm{~cm}$ (7.4 feet), the navel being situated in the middle, at $113 \mathrm{~cm}^{4}$. The artist gives two explanations for increasing the height of the proportional figure : first, policemen in popular crime stories were always about 6 feet tall, which corresponds to $183 \mathrm{~cm}$ in the metric system, and second, this height of six feet would facilitate more correspondence between the metric system and the anthropomorphistic measurements of Anglo-American culture ${ }^{42}$. Especially the first reason-policemen being six feet tall - encourages the assumption that Le Corbusier took the Modulor by far less seriously than his followers.

The dimensions chosen by Le Corbusier correspond approximately to the proportions of the Golden Section, a system which is not entirely coherent, though. Leading to irrational numeral proportions, the sectio aurea is hardly suitable for architectural practice. For this reason, the Golden Section was very rarely applied in architecture. Utilizing the Golden Section was not the only return to old traditions initiated by Le Corbusier. Just like Vitruvius, Le Corbusier deduced the body height from the assumption, that a fully grown man would be six feet tall. Even the man with the out-streched arms was familiar and can be linked to Vitruvius' figure " homo ad circulum" (fig. 6).

Le Corbusier, Der Modulor, Stuttgart, Deutsche Verlags-Anstalt, $5^{c}$ ed., 1985 (first edition in French : Le Modulor, Boulogne, Éditions de l'Architecture d'Aujourd'hui, 1950), p. II5-117.

Stanislaus von Moos, Le Corbusier. Elemente einer Synthese, Frauenfeld-Stuttgart, Huber, 1968, p. 398-406; H.-W. Kruft, Geschichte der Architekturtheorie..., op. cit., p. 328, 463-464; Le Corbusier, une encyclopédie, Paris, Centre Georges Pompidou, 1987, p. 259-26r. Further reading on the first versions : Le Corbusier, Sketchbooks, 4 vols, New York-Cambridge (Mass.), MIT Press, 1981, II (1950-1954), (passim, on the reception); Eva-Marie Neumann, "Architectural Proportion in Britain 1945-1957 ", Architectural History, XXXVI, 1996, p. 197-221. For Le Corbusier's sources, e.g. his use of traditional ideas about proportion and the Golden Section see Judi Loach, "Le Corbusier and the Creative Use of Mathematics ", British Journal for the History of Science, XXXI/2, 1998, p. 185-2Is (I owe this reference to J.V. Field).

40 Le Corbusier, Der Modulor..., op. cit., p. 36 and p. 176; J. Loach, Le Corbusier... op. cit., p. 200-20r.

4I Le Corbusier, Der Modulor..., op. cit., p. 36-68.

42 Ibid., p. 56. 


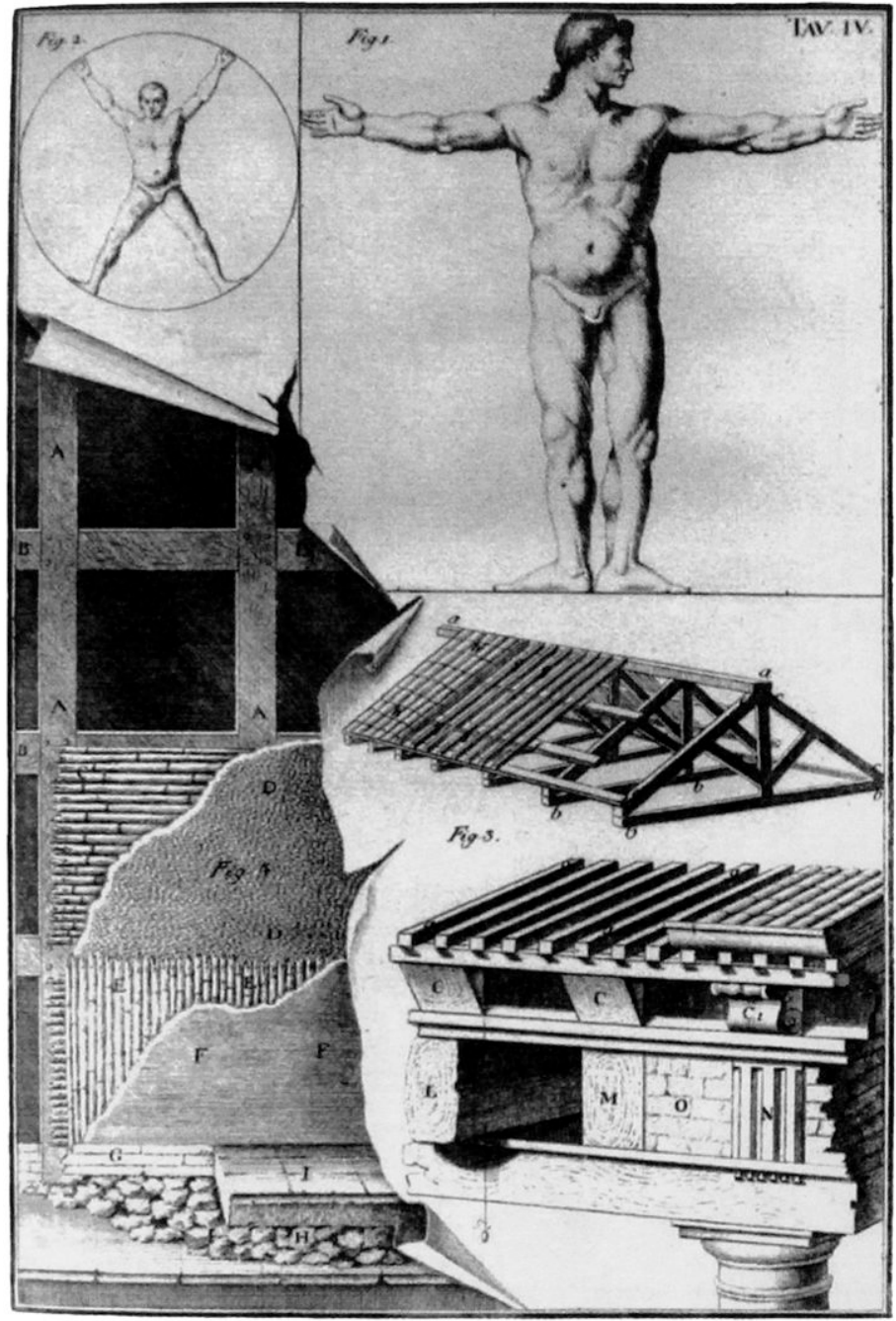

FIG. 6

Berardo Galiani, Vitruvian Men from L'architettura di M. Vitruvio Pollione colla traduzione italiana e commento del Marchese Berardo Galiani, Naples, 1758, p. 94 . 
As an anthropomorphist measurement, this figure was familiar to both ancient and Byzantine measurement systems as well as to modern building practice. In conclusion, Le Corbusier's Modulor stood for an anachronistic tradition by propagating the Golden Section as well as a figure of proportion with roots in antiquity.

The Modulor by Le Corbusier was explicitly directed against the introduction of the meter and the decimal system : Le Corbusier accused the meter of being abstract, bloodless and without emotion and describes its use as degenerating architecture ${ }^{43}$. The reason for these polemics presumably is an effort to defend modern architecture against its critics. In fact, since the 1930s, modern architecture had been defined as cold, void, dull, trivial and soulless, for instance by the German philosopher Ernst Bloch, who had emigrated to the USA in $19388^{44}$. We could possibly view the revival of anthropomorphism in the form of the Modulor as an utopia, emphasizing the romantic desire for a type of architecture that is humane. Anthropomorphism as an anthropological constant would indicate that it has two functions : during Antiquity and the Renaissance it served as a means to achieve social advancement, and in modern time it became a metaphor for an architectural utopia. This, finally, leads me to conclude that anthropomorphism can be perceived, in anthropological terms, as a constant notion, which is constant in its quality to match the individual demands of protagonists of very different periods in the history of architecture.

\section{Appendix: \\ Scale with units of measurement according to Vitruvius' canon}

\begin{tabular}{|c|c|c|c|c|}
\hline Vitruvius & digiti & Proportions & Greek & English \\
\hline homo & 96 & $1 / I$ & 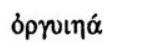 & Fathom \\
\hline \multirow[t]{3}{*}{ cubitus } & 24 & $I / 4$ & $\pi \hat{\imath} \chi \cup \varsigma$ & Cubit \\
\hline & 20 & $5 / 24$ & $\pi v \gamma \omega \dot{\omega}$ & \\
\hline & 18 & $3 / 16$ & $\pi v \gamma \mu \eta \dot{~}$ & \\
\hline pes & 16 & $1 / 6$ & $\pi 0 u ́ \varsigma$ & Foot \\
\hline caput & 12 & $\mathrm{I} / 8$ & $\sigma \pi \imath \delta \alpha \mu \eta \dot{~}$ & Span \\
\hline \multirow[t]{3}{*}{ facies* } & II & $\mathrm{II} / 96$ & 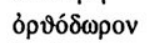 & \\
\hline & I0 & $5 / 48$ & $\lambda \iota \chi \alpha ́ \alpha$ & \\
\hline & 8 & $1 / 12$ & $\delta ı \chi \alpha ́ \alpha$ & Palm \\
\hline \multirow[t]{2}{*}{ palmus } & 4 & $\mathrm{I} / 24$ & $\pi \alpha \lambda \alpha \iota \sigma \tau \eta \dot{~}$ & Little Palm \\
\hline & 2 & $\mathrm{I} / 48$ & 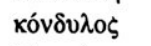 & Two Inches \\
\hline digitus & I & $1 / 96$ & 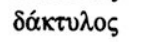 & One Inch \\
\hline
\end{tabular}

43 Ibid., p. 19, 20, 33, 223.

44 Ernst Bloch, Das Prinzip Hoffnung, 3 vols., Frankfurt, Suhrkamp, 1974 (first edition 1959), II, p. 858-863, esp. p. 86I including a review on Le Corbusier (written between 1938 and 1947 in the USA). 